\title{
MODERN FORMS AND METHODS OF THE ARMED FIGHT AFTER EXPERIENCE OF LOCAL WARS OF CONTEMPORANEITY
}

\author{
A. Fedenko, Y. Salnik
}

The analysis of scientific and technical policy of countries of NATO shows its orientation towards forming of material and technical base of development of armament and military materiel with the use of highly technological technologies. Especially swift development was achieved in terms of high-precision weapon. The latest researches allow to substantially increase capabilities of conventional armaments, create the on principle new types of weapon, which greatly differ from the known facilities of the armed fight. The use of such weapon results in changes in maintenance of the armed fight, organization and practice of embay.

Keywords: high-precision weapon, experience of local wars of contemporaneity, automated reconnaissance systems.

355.469

. . ок чов, . . ривизюк, . . лущенко

ввівський інститут ухопутних військ, ввів

cm тті проведений н ліз з стосув ння військ у збройних конфлікт х суч сності, н основі якого розгляд ються кту льні пит ння вз ємозв'язку вогневого ур жеення противник із осн щенням ухопутних військ під ч с проведення опер цій.

лючові слов : опер ція, вогневе ур ження, розвідув льно-інформ ційне поле, систем озброєння $i$ військової техніки.

\section{ступ}

ост новк проблеми. вітов пр ктик лок льних війн і збройних конфліктів суч сності, теоретичні розробки вчених, які грунтуються н н лізі вітчизняного і світового досвіду в цій сфері, доводять, що м йбутнє ухопутних військ ( ) прямо з лежить від осн щення їх новими, перспективними зр зк ми озброєння і військової техніки ( ), які створені н основі ост нніх досягнень н уково-технічного прогресу.

3 г льнення досвіду 3 стосув ння військ збройних сил осійської едер ції н івнічному

вк зі, ст н яких м є неб г то відмінностей від ст ну бройних сил кр їни ( ), виявився дост тньо трив лим: особливості суч сного озброєння т кі, що досягнути викон ння пост влених з вд нь без бойових втр т військ (сил) неможливо.

н ліз ведення опер цій у суч сних збройних конфлікт х пок зує, що вони здійснюються в основному в дв ет пи: перший ет п - лок ліз ція зони бойових дій; другий - здійснення вогневого ур ження (розгрому) противник .

$$
\text { першому ет пі широко } 3 \text { діюються }
$$
д лекобійні вогневі з соби з метою придушення т знищення зброї великої д льності противник , 3 собів розвідки, центрів упр вління, скл дів (6 з) озброєння т інших в жливих об'єктів. сновними результ т ми першого ет пу опер ції у конфлікті повинні бути: лок ліз ція зони бойових дій шляхом розгорт ння опорних пунктів і блок-постів ( i

), всередині якої діють групи військової розвідки, 3 метою вст новлення технічних 3 собів розвідки ( ) i здобуття д них для вогневого ур ження; вст новлення розвідув льно-вогневого контролю н д територією зони, т кож висув ння Т розгорт ння основних військ (сил).

другому ет пі опер ції передб ч ється знищення знову виявлених д лекобійних з собів ур ження, 6 з, поновлених центрів упр вління, т кож противник, який н м г ється вирв тися із зони, бо зосередитися в більш велике угрупов ння. ри цьому розвідк і вогневе ур ження здійснюються доти, поки ф кт незд тності противник до ініці тивних і орг нізов них бойових дій не ст не очевидним.

ри необхідності в кінці другого ет пу опер ції, коли ст є неможливим д льнє вогневе ур ження 3 низкою причин, ч стин основних сил здійснює рейдові дії, ле метою їх є не знищення противник уд р ми військ, розбудов системи i , які дозволяють здійснити ефективне вогневе ур ження противник .

оловним результ том другого ет пу опер ції $€$ контрольов ний вогневий розгром противник , при цьому з г льновійськові ч стини і підрозділи вогнем дод ної, підтримуючої ртилерії, ві ції, т кож т нків i 3 відст ні, як 3 безпечує 
недосяжність для ручних протит нкових з собів противник, послідовно, по ч стин х знищують сили противник, що з лишились. е дозволяє пл номірно зосереджув ти зусилля н потрібних н прямк $\mathrm{x}$.

н ліз ост нніх досліджень і публік цій. к свідчить н ліз російських і вітчизняних розробок, при н несенні ур ження противнику в т ктичній т опер тивній глибині перев г н д ється р кетним військ м і ртилерії, тому що при порівняльному н лізі їх з рмійською ві цією пок зники, т кі як, н прикл д, ре кція в 2,5-4 р зи в ост нній більше (дивізіон 219 - 5-6 хв., $\quad-24$ - 13-24 хв.); відсутність у ві ції р птовості (шум двигунів 3 10 км); ефективність вогню для ур ження броньов них об'єктів при використ нні високоточних сн рядів т кож н боці ртилерії (« р снополь» розхід н один об'єкт 1,1; « турм- »-2,9).

ким чином, як т ктичн , т к і економічн оцінк викон ння вогневих з вд нь (н віть без мортиз ції в ртості ві ційної і р кетно- ртилерійської техніки) пок зує, що основний обсяг вогневих з вд нь у конфлікті повинен н леж ти р кетним військ м і ртилерії.

н ліз ходу опер цій в суч сних конфлікт х пок зує, що основний принцип розвідув льно вогневої опер ції ( ) - відхід від дуельних ситу цій вз ємного знищення до одностороннього вогневого ур ження об'єктів противник сформульов ний вірно (втр ти едер льних військ осії н 15.10.1999 року - 80 чоловік, чеченських 6 ндформув нь - 1,5-2 тис. чоловік).

ет ст тті. основі проведеного н лізу визн чил сь основн проблем глибокого вогневого ур ження - проблем створення н всій території збройного конфлікту розвідув льно-інформ ційного поля в інтерес х н несення ефективних уд рів.

ж ль, н явні технічні з соби розвідки, які стоять н озброєнні, є в основному оптичними і не з безпечують контролю н всю глиби ну досяжності ртилерії і тим більше р кетних комплексів. ільш того, ці з соби, як і іноземні розвідки, призн чені для виявлення об'єктів противник в меж $\mathrm{x}$ зон прямої видимості т не прид тні для вирішення визн ченої проблеми.

\section{сновний м тері л}

ля створення розвідув льно-інформ ційного поля 3 метою отрим ння повної т своєч сної інформ ції для підготовки т н несення ефективних уд рів по противнику необхідно м ти н озброєнні: - розвідув льний комплекс н основі кустичних д в чів, що вст новлюються дист нційно пострілом; - p діолок ційний комплекс н борту вертольот ;

- розвідув льний комплекс з телескопічною пл тформою (10-20 м), що дозволяє проводити розвідку в оптичному, I ді п зон х, режимі, визн чити координ ти цілей, здійснюв ти їх л зерну підсвітку;

- розвідув льні дист нційно-пілотов ні п р ти 3 телевізійною п р турою оптичного і ді п зонів, для здійснення візу льного контролю, з безпечення корегув ння вогню, здійснення л зерної підсвітки для ур ження високоточними сн ряд ми;

- p діолок ційний комплекс розвідки г рм т противник , який веде вогонь.

сі сили, з соби розвідки й ур ження противник повинні бути з мкнуті в єдину втом тизов ну систему упр вління ( ) розвідув льно-вогневої системи ( ). ерез відсутність т ких систем і комплексів це вимушено компенсується чисельністю військ і діями мех нізов них, т нкових i еромобільних підрозділів. ому н явн ситу ція не $з$ побіг $є$ бойовим втр т м своїх військ. едопустимо великі бойові втр ти виник ють при неминучих вогневих конт кт х у т ких типових ситу ціях:

- т к противником з близької відст ні (з сідок) підрозділів, які обл днують і ;

- вогонь н ур ження із з сідок із використ нням стрілецької зброї, і без спроб т к;

- вогневий н п д з под льшою т кою із з сідки н підрозділи т колони, що висув ються в передбойових порядк х із з стосув нням мінних полів і інженерних з городжень.

ктивних н ступ льних дій без знищення д лекобійних вогневих з собів, основних елементів оборони противник, військ повинні уник ти через можливі великі втр ти. ля усунення можливих втр т під ч с вищерозглянутих ситу цій необхідно к рдин льно підвищити живучість н явних зр зків легкоброньов ної техніки. ожливістю мережі 3 підвищення живучості можуть бути: вст новлення протикумулятивних екр нів (сіток), протикульних зовнішніх елементів підсилення броньов ного з хисту, протиосколкових підбоїв, внутрішніх протикумулятивних екр нів, протиосколкових м тів, перегородок, спеці льного дообл дн ння п ливних 6 ків. комплексі 3 підвищенням живучості техніки можливо суттєво знизити вірогідність втр т особового скл ду. ртість можливих з ходів з підсилення протикульної т протикумулятивної стійкості н явних зр зків легкоброньов ної техніки суттєво менше в ртості розробки нових н логічних зр зків. $\mathrm{K}$ доробк може бути здійснен в р мк х модерніз ції будьякого зр зК озброєння.

ищевк $з$ ні типові ситу ції вогневих конт ктів $\mathrm{x}$ р ктеризується швидкоплинністю т к із близької відст ні, коли ч с ре кції упр вління вогнем, з в нт женість і польотний ч с сн рядів ртилерії 
(ч с підльоту ві ції) не з безпечу ють ур ження т куючого противник. сновний уд $\mathrm{p}$ повинен бути спрямов ний н вогневі з соби с мого підрозділу. цьому контексті з слуговує н ув гу ідея створення н $б$ зі т нк спеці лізов ної м шини конт ктного бою. рототипом зг д ної м шини, що м є велику вогневу потужність, є д вно призн ний 3 сіб т кого роду, як 23-4, як з стосовув л сь ще в фг ніст ні для вогневої підтримки н земних вогневих з собів. к бойов м шин може не тільки ур ж ти легкоброньов ні цілі, ще і «обріз ти» т нк: якщо всі прил ди ведення спостереження і стрільби будуть знищені, т нк не буде «б чити», відповідно ур ж ти цілі.

ільш того, т нков 63 може ст ти основною для сімейств м шин, які призн чені для розміщення рухомих пунктів упр вління і розвідки, перевезення особового скл ду, боєприп сів, продовольств т інше. зв'язку з тим, що ре льним $з$ собом ур ження подібного ряду м шин будуть , вся ця технік повинн бути осн щен ктивним і п сивним протир ке тним з хистом.

\section{иснов ки}

ким чином, для координ льного покр щення ситу ції розвитку необхідним ст є підхід, суть якого поляг є в тому, що підвищення бойової потужності здійснюється не тільки шляхом кількісного н рошув ння з собів боротьби, й 3 p хунок комплексного, системного підходу. обто, необхідно розробляти не просто окремі, н віть дуже ефективні зр зки , готові функціон льні бойові системи (комплекси), в яких н основі суч сних інформ ційних технологій інтегров ні з соби ур ження і відповідні з соби розвідки, зв'язку, н віг ції, м скув ння, комплексного з хисту т інше.

озвиток системи у н прямку іï зб л нсов ності н основі системного підходу дозволить суттєво покр щити технічну осн щеність підрозділів і ч стин із вр хув нням перспективних форм і способів їх з стосув ння в лок льних війн х і конфлікт х сторіччя.

\section{писок літер тури}

1. г фонов. . ормы и способы применения группировок войск (сил) в вооруженных конфликт $x$ u лок льных войн $x$ / . . г фонов, . . нжурин // оенн я мысль. - 1996. - № 2. - . 20-24.

2. л хончев. . звитие форм и способов ведения военных действий в н ч ле XXI век / . . л хончев, . . един // рубежное военное обозрение. - 2003. - № 4. - . 25-28.

3. ер сименко . . озвиток т ктики н основі досвіду лок льних воєн $i$ збройних конфліктів / . . ер сименко, . . ибулько, . . ндросов// ук $i$ оборон . - 2004. - №3. - . 29-32.

4. ормильцев . . ухопутные войск : перспективы строительств и р звития / . . ормильцев // оенн я мысль. - 2003. - №5. - . 2-16.

дійшл до ред кції 17.12.2008

ецензент: доктор технічних н ук, ст рший н уковий співробітник . . орольов, уковий центр ьвівського інституту ухопутних військ, ьвів .

$$
\text { . . ок чев, . . ривизюк, . . лущенко }
$$

ст тье проведён н лиз применения войск в вооружённых конфликт х соврем енности, н основе которого р ссм трив ются кту льные вопросы вз имосвязи огневого пор жения противник с осн щением ухопутных войск во время проведения опер ций.

лючевые слов : опер иия, огневое пор жение, р зведов тельно-информ иионное поле, систем вооружения и военной техники.

\title{
NECESSARY CHANGES IN THE PRESENT SYSTEM OF ARMAMENT AND MILITARY MATERIEL OF THE LAND FORCES OF THE UKRAINIAN ARMED FORCES
}

\author{
S. V. Bokachov, L. P. Kryvyziuk, V. S. Gluschenko
}

The article provides analysis of the employment of the forces in current military conflicts, on the basis of which vital issues of interrelation of fire striking of enemy and equipment of Land Forces during the conduct of operations is considered.

Keywords: operation, fire striking, intelligence - informational field, system of armament and military mate riel. 